\title{
SISTEM PENDUKUNG KEPUTUSAN MAHASISWA BERPRESTASI MENGGUNAKAN METODE ANALYTICAL HIERARCHY PROCESS (AHP) (STUDI KASUS: UNIVERSITAS MAJALENGKA)
}

\author{
Tri Ferga Prasetyo ${ }^{1}$, Chandra Kusumah ${ }^{2}$ \\ ${ }^{1}$ Program Studi Teknik Informatika, Fakultas Teknik,Universitas Majalengka \\ Jl. K.H Abdul Halim No. 103 Majalengka 45418 \\ Telp. (0233) 281496 \\ ${ }^{2}$ Jurusan Teknik Informatika, Fakultas Teknik, Universitas Majalengka \\ Jl. K.H Abdul Halim No. 103 Majalengka 45418 \\ E-mail: triferga.prasetyo@gmail.com, chandra.rygart@gmail.com
}

\begin{abstract}
University Majalengka (UNMA) annually organize elections outstanding students Bachelor (S1), students who achieved high achievements in both curricular, curricular, and extracurricular accordance with prescribed criteria. To facilitate the selection of outstanding students need to be made of a system which is able to provide the results of student achievement winner and simplify the process of selection of outstanding students. The method used in the PRS Outstanding Student Selection using Analytical Hierarchy Process (AHP) which can take into account all criteria decision support student elections quickly and easily. AHP is quite effective in simplifying and accelerating the decision-making process to solve these problems into parts. SPK design Outstanding Student Selection using system development methodology Extreme Programming and UML modeling. Extreme Programming consists of the stages of planning, designing, coding and testing. System output is presented in the form of numeric calculation results based on AHP and Outstanding Student Selection guidelines which may be further considered by the decision maker. Based on the test result that the existing functions can be run well so that CMS can meet user needs, such as helping the student data collection process, the judging and processing of election participants achieving students. SPK can display information according to the user inputting precise and easy to use. Instructions for use DSS to help users. SPK safe from unauthorized access.
\end{abstract}

Kata Kunci: SPK (Sistem Pendukung Keputusan), AHP (Analytical Hierarchy Process), XP(Extreme Programming)

\section{PENDAHULUAN}

Proses pemilihan mahasiswa berprestasi merupakan permasalahan yang melibatkan banyak kriteria yang dinilai atau multikriteria, sehingga dalam penyelesaiannya diperlukan sebuah sistem pendukung keputusan dengan multikriteria. Salah satu metode sistem pendukung keputusan yang multikriteria adalah Analytical Hierarchy Process (AHP). AHP ini cukup efektif dalam menyederhanakan dan mempercepat proses pengambilan keputusan dengan memecahkan persoalan tersebut ke dalam bagian-bagiannya.(Magdalena,2012).

Mahasiswa diharapkan tidak hanya menekuni ilmu dalam bidangnya saja, tetapi juga beraktivitas untuk mengembangkan soft skills-nya agar menjadi lulusan yang mandiri, penuh inisiatif, bekerja secara cermat, penuh tanggung jawab dan tangguh. Kemampuan ini dapat diperoleh mahasiswa melalui pembekalan secara formal dalam kurikulum pembelajaran, kokurikuler, dan ekstrakurikuler. (DIKTI, 2015).

Oleh karena itu, Universitas Majalengka perlu melakukan identifikasi mahasiswa yang berprestasi di kedua kompetensi itu dan yang terbaik perlu diberi penghargaan sebagai mahasiswa yang berprestasi (Mawapres). Pemilihan Mawapres merujuk pada kinerja individu mahasiswa yang memenuhi kriteria pemilihan yang ditetapkan DIKTI pada tahun 2015, yaitu: Indeks Prestasi Kumulatif (IP seluruh matakuliah yang lulus) rata-rata minimal 3.00, karya tulis ilmiah, prestasi/kemampuan yang diunggulkan, bahasa Inggris, dan kepribadian. 
Untuk memudahkan pemilihan mahasiswa berprestasi perlu dibuat suatu sistem yang mampu memberikan hasil pemenang mahasiswa berprestasi dan mempermudah proses pemilihan mahasiswa berprestasi. Untuk itu, diperlukan suatu Sistem Pendukung Keputusan (SPK) yang penyelesaian masalahnya menggunakan metode AHP yang dapat memperhitungkan segala kriteria yang mendukung pengambilan keputusan pemilihan mahasiswa secara cepat, mudah dan dalam proses pengolahan data pengambilan keputusan dapat melakukan perangkingan untuk menentukan mahasiswa berprestasi.(Yulianto, 2014)

\section{METODE PENELITIAN}

\section{A. Metode Pengumpulan Data}

Dalam penulisan laporan tugas akhir ini penulis menggunakan teknik pengumpulan data sebagai berikut:

a. Wawancara

Wawancara merupakan teknik pengumpulan data berupa tanya jawab dengan Biro Administrasi Akademis dan Kemahasiswaan (BAAK) Universitas Majalengka untuk memperoleh data-data yang dibutuhkan diantaranya aspek-aspek penilaian mahasiswa berprestasi, termasuk nilai IPK, karya tulis ilmiah, prestasi/kemampuan yang diunggulkan, dan bahasa Inggris;

b. Studi Pustaka

Merupakan teknik pengumpulan data dengan cara mempelajari dan membaca berbagai macam buku, laporan, artikel dan jurnal yang ada kaitannya dengan penelitian;

c. Observasi

Observasi merupakan metode pengumpulan data melalui pengamatan yang dilakukan secara langsung terhadap objek penelitian yaitu sistem pendukung keputusan mahasiswa berprestasi. Dengan menggunakan pencatatan secara sistematika terhadap fakta-fakta yang ada hubungannya dengan masalah yang sedang di teliti. Penelitian ini dilaksanakan di Biro Administrasi Akademis dan Kemahasiswaan (BAAK) Universitas Majalengka.

\section{B. Komponen Penilaian}

Pemilihan Mawapres merujuk pada kinerja individu mahasiswa yang memenuhi kriteria pemilihan yang terdiri atas lima unsur, yaitu:

1. Indeks Prestasi Kumulatif

Indeks Prestasi Kumulatif (IPK) adalah seluruh nilai matakuliah rata-rata yang lulus sesuai dengan aturan masing-masing perguruan tinggi dan disahkan oleh Dekan. IPK hanya dinilai dalam proses pemilihan Mawapres sampai pemilihan tingkat perguruan tinggi;

2. Karya Tulis Ilmiah

Karya tulis ilmiah yang dimaksud merupakan sebuah tulisan ilmiah hasil dari kajian pustaka dari sumber terpercaya yang berisi solusi kreatif dari permasalahan yang dianalisis secara runtut dan tajam, serta diakhiri dengan kesimpulan yang relevan;

3. Prestasi/Kemampuan yang Diunggulkan Prestasi/kemampuan unggulan yang diraih selama menjadi mahasiswa khususnya kegiatan kokurikuler dan ekstrakurikuler yang mendapatkan pengakuan dan atau penghargaan yang berdampak positif pada perguruan tinggi dan masyarakat. Jumlah prestasi yang diunggulkan maksimal 10 jenis. Penilaiannya dapat dilihat pada tabel 1 dan 2;

Tabel 1 Penialaian Pencapaian

\begin{tabular}{|c|c|c|c|c|c|}
\hline \multirow{2}{*}{ Tingkat } & \multirow{2}{*}{$\begin{array}{l}\text { Pen } \\
\text { ca } \\
\text { paia } \\
\text { n }\end{array}$} & \multicolumn{2}{|c|}{$\begin{array}{l}\text { Sesuai } \\
\text { Bidang }\end{array}$} & \multicolumn{2}{|c|}{$\begin{array}{c}\text { Bidang } \\
\text { Lainnya }\end{array}$} \\
\hline & & $\begin{array}{l}\text { Indivi } \\
\text { du }\end{array}$ & $\begin{array}{l}\text { Kelom } \\
\text { pok }\end{array}$ & $\begin{array}{l}\text { Indivi } \\
\text { du }\end{array}$ & $\begin{array}{l}\text { Kelom } \\
\text { pok }\end{array}$ \\
\hline \multirow{3}{*}{$\begin{array}{l}\text { Internasi } \\
\text { onal }\end{array}$} & $\begin{array}{l}\text { Juar } \\
\text { a } 1\end{array}$ & 10 & 5 & 7 & 3.5 \\
\hline & $\begin{array}{l}\text { Juar } \\
\text { a } 2\end{array}$ & 8 & 4 & 5 & 2.5 \\
\hline & $\begin{array}{l}\text { Juar } \\
\text { a } 3\end{array}$ & 4 & 2 & 3 & $\begin{array}{l}1.2 \\
5\end{array}$ \\
\hline \multirow{3}{*}{ Regional } & $\begin{array}{l}\text { Juar } \\
\text { a } 1\end{array}$ & 8 & 4 & 5 & 2.5 \\
\hline & $\begin{array}{l}\text { Juar } \\
\text { a } 2\end{array}$ & 6 & 3 & 4 & 2 \\
\hline & $\begin{array}{l}\text { Juar } \\
\text { a } 3\end{array}$ & 3 & 1.5 & 2 & 1 \\
\hline \multirow{3}{*}{ Nasional } & $\begin{array}{l}\text { Juar } \\
\text { a } 1\end{array}$ & 6 & 3 & 4 & 2 \\
\hline & $\begin{array}{l}\text { Juar } \\
\text { a } 2\end{array}$ & 4 & 2 & 3 & 1.5 \\
\hline & $\begin{array}{l}\text { Juar } \\
\text { a } 3\end{array}$ & 2 & 1 & 1.5 & $\begin{array}{l}0.7 \\
5\end{array}$ \\
\hline
\end{tabular}




\begin{tabular}{|c|l|r|r|r|c|}
\hline \multirow{4}{*}{ Provinsi } & $\begin{array}{l}\text { Juar } \\
\text { a 1 }\end{array}$ & 4 & 2 & 3 & 1.5 \\
\cline { 2 - 5 } & $\begin{array}{l}\text { Juar } \\
\text { a 2 }\end{array}$ & 2 & 1 & 1.5 & $\begin{array}{c}0.7 \\
5\end{array}$ \\
\cline { 2 - 6 } & $\begin{array}{l}\text { Juar } \\
\text { a 3 }\end{array}$ & 1 & 0.5 & 0.5 & $\begin{array}{c}0.2 \\
5\end{array}$ \\
\hline
\end{tabular}

Tabel 2 Penilaian Penghargaan/Pengakuan

\begin{tabular}{|l|c|c|}
\hline Tingkat & Individu & Kelompok \\
\hline Provinsi & 2 & 1 \\
\hline Nasional & 4 & 2 \\
\hline Regional & 6 & 3 \\
\hline Internasional & 8 & 4 \\
\hline
\end{tabular}

4. Bahasa Inggris/Asing

Penilaian bahasa Inggris/asing dilakukan melalui dua tahap yaitu (1) penulisan ringkasan (bukan abstrak) berbahasa Inggris/asing dari karya tulis ilmiah, dan (2) presentasi dan diskusi dalam bahasa Inggris/asing. Ringkasan berisi latar belakang, rumusan masalah, metodologi, hasil dan simpulan. Ringkasan terdiri atas 500-750 kata, ditulis dengan menggunakan 1,5 spasi di kertas berukuran A4. Penulisan ringkasan bertujuan untuk menilai kecakapan mahasiswa dalam menulis berbahasa Inggris/asing. Presentasi dengan topik tertentu yang dilanjutkan dengan diskusi bertujuan untuk menilai kemampuan mahasiswa dalam berkomunikasi lisan.;

5. Kepribadian

Kisi-kisi penilaian terdiri atas: sikap sesuai dengan prestasi yang dicapai, cenderung berpikiran maju, dan tidak menunjukkan perilaku yang tidak patut. Hasil penilaian kepribadian tidak dikuantifikasikan, tetapi dijadikan syarat untuk menentukan kepatutan sebagai Mawapres.

Komponen penilaian untuk pemilihan mahasiswa berprestasi yang dilakukan di Universitas Majalengka yaitu:

1. IP Kumulatif : $\frac{\text { IPK }}{4} \times 100$;

2. Karya Tulis Ilmiah Nilai Tulisan + Nilai Presentasi

Nilai Tertinggi Peserta

3. Prestasi/Kemampuan yang Diunggulkan : $\frac{\text { Nilai yangdiperoleh }}{\text { Nilai Tertinggi Peserta }} \times 100$

4. Bahasa Inggris

$\frac{\text { Nilai yangdiperoleh }}{\text { Nilai Tertinggi Pegerta }} \times 100$.

\section{Mengimplementasikan Model}

Proses penentuan prioritas menggunakan metode AHP dimulai dari perumusan masalah yaitu proses untuk menentukan kriteria dan alternatif dari penyeleksian. Dalam kasus penyeleksian mahasiswa berprestasi kali ini kriterianya ada lima yaitu Indeks Prestasi Kumulatif (IPK), Karya Tulis Ilmiah, prestasi yang diunggulkan, dan Kemampuan berbahasa Inggris. Sedangkan untuk alternatifnya panitia seleksi mahasiswa berprestasi memilih beberapa calon berpotensi untuk mengikuti seleksi selanjutnya. Hierarki fungsionalnya seperti ditunjukan pada gambar 1 .

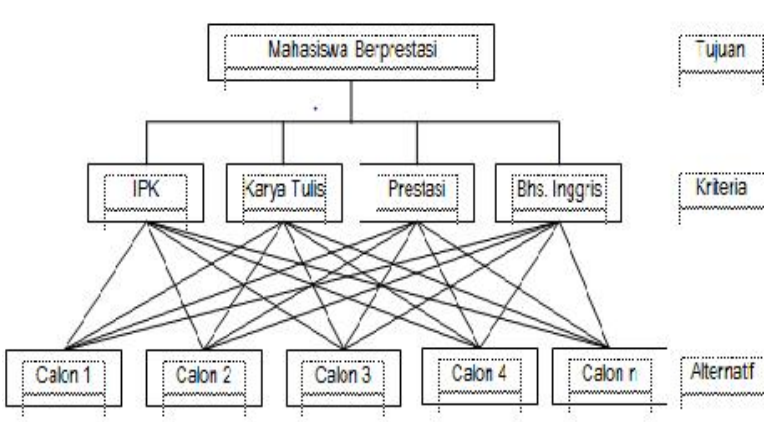

Gambar 1 Struktur Hierarki AHP

\section{Membuat Matriks Berpasangan}

Pada tahap ini dilakukan penilaian perbandingan antara satu kriteria dengan kriteria yang lain. Penilaian bisa dilihat dalam tabel 3 .

Tabel 3 Matriks Perbandingan berpasangan

\begin{tabular}{|l|l|l|l|l|}
\hline & $\begin{array}{l}\text { IP } \\
\text { K }\end{array}$ & $\begin{array}{l}\text { KT } \\
\text { I }\end{array}$ & $\begin{array}{l}\text { Prest } \\
\text { asi }\end{array}$ & $\begin{array}{l}\text { B. } \\
\text { Inggris }\end{array}$ \\
\hline IPK & 1 & 0.33 & 0.5 & 0.5 \\
\hline KTI & 3 & 1 & 2 & 2 \\
\hline Prestasi & 2 & 0.5 & 1 & 1 \\
\hline $\begin{array}{l}\text { B. } \\
\text { Inggris }\end{array}$ & 2 & 0.5 & 1 & 1 \\
\hline Jumlah & 8 & 2.33 & 4.5 & 4.5 \\
\hline
\end{tabular}

Angka 1 pada kolom IPK baris IPK menggambarkan tingkat kepentingan yang sama antara IPK dengan IPK, sedangkan angka 3 pada kolom IPK baris karya tulis menunjukan karya tulis sedikit lebih penting dibandingkan IPK. Angka 0.33 pada kolom karya tulis baris IPK merupakan hasil perhitungan 1/nilai pada kolom IPK baris karya tulis yaitu 3. Angkaangka yang lain diperoleh dengan cara yang sama. 


\section{E. Membuat Matriks Nilai Kriteria}

Matriks ini diperoleh dengan rumus nilai baris kolom baru $=$ Nilai baris-kolom lama/jumlah masing-masing kolom lama. Hasil perhitungan dalam bentuk matriks bisa dilihat dalam tabel 4.

Tabel 4 Matriks Nilai Kriteria

\begin{tabular}{|c|c|c|}
\hline karya tulis & 0.42 & \\
\hline $\begin{array}{l}\text { Nilai baris IPK kolom } \\
\text { prestasi }\end{array}$ & $0.5 \times 0.23$ & 0.12 \\
\hline $\begin{array}{l}\text { Nilai baris IPK kolom Bhs. } \\
\text { Inggris }\end{array}$ & $0.5 \times 0.23$ & 0.12 \\
\hline $\begin{array}{l}\text { Nilai baris karya tulis } \\
\text { kolom IPK }\end{array}$ & $3 \times 0.12$ & 0.36 \\
\hline $\begin{array}{l}\text { hil siobbatris karya tulis } \\
\text { kolamikarya tulis }\end{array}$ & $1 \times 0.42$ & 0.42 \\
\hline $\begin{array}{l}\text { Nilai.42 baris karya tulis } \\
\text { kolarnoprestasi }\end{array}$ & $2 \times 0.23$ & 0.46 \\
\hline $\begin{array}{l}\text { Nilai. } 23 \text { baris karya tulis } \\
\text { kolom Bhs. Inggris }\end{array}$ & $2 \times 0.23$ & 0.46 \\
\hline $\begin{array}{l}\text { Nilai baris prestasi kolom } \\
\text { IPK }\end{array}$ & $2 \times 0.12$ & 0.24 \\
\hline $\begin{array}{l}\text { Nilai baris prestasi kolom } \\
\text { karya tulis }\end{array}$ & $0.5 \times 0.42$ & 0.21 \\
\hline $\begin{array}{l}\text { Nilai baris prestasi kolom } \\
\text { prestasi }\end{array}$ & $1 \times 0.23$ & 0.23 \\
\hline $\begin{array}{l}\text { Nilai baris prestasi kolom } \\
\text { Bhs. Inggris }\end{array}$ & $1 \times 0.23$ & 0.23 \\
\hline $\begin{array}{l}\text { Nilai baris Bhs. Inggris } \\
\text { kolom IPK }\end{array}$ & $2 \times 0.12$ & 0.24 \\
\hline $\begin{array}{l}\text { Nilai baris Bhs. Inggris } \\
\text { kolom karya tulis }\end{array}$ & $0.5 \times 0.42$ & 0.21 \\
\hline $\begin{array}{l}\text { Nilai baris Bhs. Inggris } \\
\text { kolom prestasi }\end{array}$ & $1 \times 0.23$ & 0.23 \\
\hline $\begin{array}{l}\text { Nilai baris Bhs. Inggris } \\
\text { kolom Bhs. Inggris }\end{array}$ & $1 \times 0.23$ & 0.23 \\
\hline
\end{tabular}

Kolom jumlah pada tabel 5 diperoleh dengan menjumlahkan nilai pada masing-masing baris tabel tersebut. Hasil perhitungan disajikan dalam tabel 6.

Tabel 6 Matriks Penjumlahan Setiap Baris

\begin{tabular}{|l|l|l|l|c|c|}
\hline & IPK & KTI & Prestasi & $\begin{array}{c}\text { B. } \\
\text { Inggris }\end{array}$ & $\begin{array}{c}\text { Jumlah } \\
\text { per } \\
\text { baris }\end{array}$ \\
\hline IPK & 0.12 & 0.14 & 0.12 & 0.12 & 0.50 \\
\hline KTI & 0.36 & 0.42 & 0.46 & 0.46 & 1.70 \\
\hline Prestasi & 0.24 & 0.21 & 0.23 & 0.23 & 0.91 \\
\hline $\begin{array}{l}\text { B. } \\
\text { Inggris }\end{array}$ & 0.24 & 0.21 & 0.23 & 0.23 & 0.91 \\
\hline
\end{tabular}

\section{Perhitungan Rasio Konsistensi}

Perhitungan ini digunakan untuk memastikan bahwa nilai rasio konsistensi $(\mathrm{CR})<=0.1$. jika ternyata nilai CR lebih besar dari 0.1, maka matriks perbandingan berpasangan harus diperbaiki. Untuk menghitung rasio konsistensi, dibuat tabel seperti terlihat dalam tabel 7 .

Perhitungan perkalian matriksnya dapat dilihat pada tabel 5 .

Tabel 5 Perkalian Matriks

\begin{tabular}{|l|l|l|l|}
\hline \multicolumn{2}{|l|}{ Deskripsi Matriks } & Range & Hasil \\
\hline Nilai baris IPK kolom IPK & $1 \times 0.12$ & 0.12 \\
\hline Nilai baris IPK kolom & $0.33 \quad$ x & 0.14 \\
\hline
\end{tabular}


Tabel 7 Perhitungan Rasio Konsistensi

\begin{tabular}{|l|c|c|c|}
\hline & $\begin{array}{c}\text { Jumlah } \\
\text { per baris }\end{array}$ & Prioritas & Hasil \\
\hline IPK & 0.50 & 0.12 & 0.62 \\
\hline KTI & 1.70 & 0.42 & 2.12 \\
\hline Prestasi & 0.91 & 0.23 & 1.14 \\
\hline B. & 0.91 & 0.23 & 1.14 \\
Inggris & & & \\
\hline
\end{tabular}

Kolom jumlah per-baris diperoleh dari kolom jumlah per baris pada tabel 6 , sedangkan kolom prioritas diperoleh dari kolom prioritas pada tabel 4. hasil merupakan penjumlahan dari jumlah per baris ditambah prioritas. Dari tabel 7, diperoleh nilai-nilai sebagai berikut :

Jumlah (penjumlahan dari nilai-nilai hasil) : 5.02

n (jumlah kriteria) : 4

$\lambda$ maks (jumlah/n) $: 5.02 / 4=1.26$

$\mathrm{Cl}(\lambda$ maks $-\mathrm{n} / \mathrm{n}):(1.26-4) / 4=-0.69$

CR (CI / IR (lihat Tabel 2.3)) :

$-0.69 / 0.90=-0.77$

Oleh karena $\mathrm{CR}<0.1$, maka rasio konsistensi dari perhitungan tersebut bisa diterima.

\section{Menghitung Hasil}

Prioritas hasil perhitungan berdasarkan langkah yang telah diuraikan di atas, kemudian direkapitulasi kedalam matriks hasil yang terlihat dalam tabel 8.

Tabel 8 Matriks Hasil

\begin{tabular}{|l|l|l|l|l|}
\hline & IPK & KTI & Prestasi & B. Inggris \\
\hline Prioritas & 0.12 & 0.42 & 0.23 & 0.23 \\
\hline
\end{tabular}

\section{HASIL DAN PEMBAHASAN}

Implementasi dari sistem pendukung keputusan mahasiswa berprestasi ini di desain dengan menggunakan visual basic.net. Dalam implementasi antarmuka ini terdapat form yang menjelaskan tentang penginputan data admin, data mahasiswa, pembobotan, penilaian, prestasi, perangkingan dan pembuatan laporan.

\section{Form Login}

Form ini digunakan untuk pemilihan hak akses pengguna yang dapat masuk ke dalam sistem dengan menggunakan ID pengguna dan password.

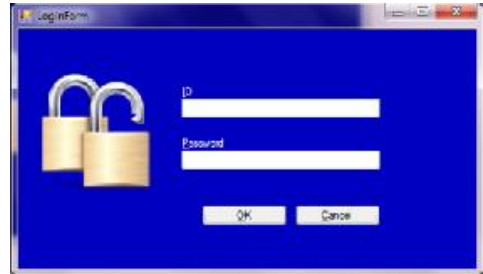

Gambar 2 Tampilan Login

\section{Form Menu utama}

Form ini digunakan untuk melihat dan memillih menu apa saja yang ada di dalam sistem pendukung keputusan mahasiswa berprestasi.

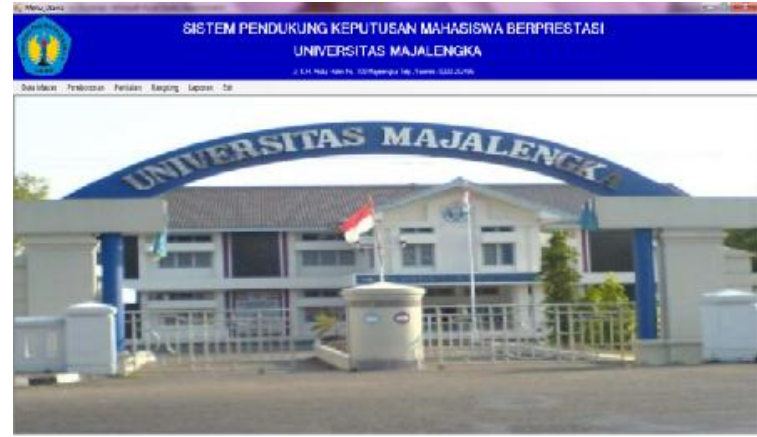

Gambar 3 Tampilan Menu Utama

\section{Form Admin}

Form ini digunakan untuk menambah dan mengubah data admin yang dapat mengakses sistem ini. Berisi ID, Nama, Password, dan Hak akses. Terdapat tabel yang akan menampilkan data admin yang sedang menggunakan sistem ini. Ketika menekan tombol edit akan tampil inputbox untuk memasukkan ID dan password yang akan di ubah tersebut. Hal ini dilakukan untuk mengamankan data yang ada sehingga seorang admin tidak dapat mengubah data admin lain tanpa sepengetahuan orang yang menjadi admin tersebut.

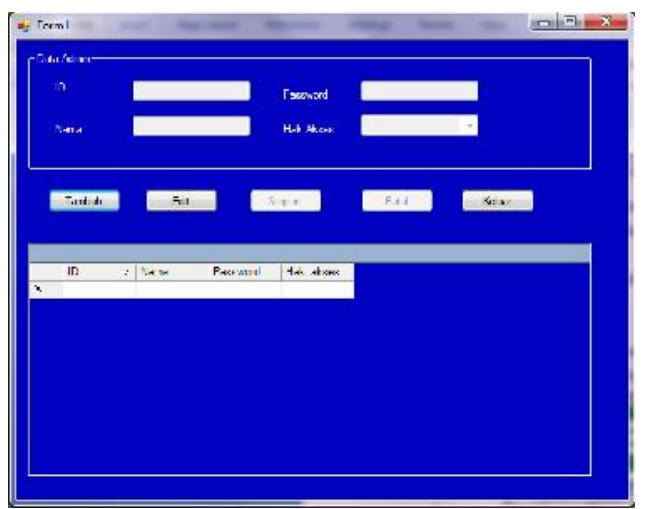

Gambar 4 Tampilan Data Admin 


\section{Form Data Mahasiswa}

Form ini digunakan untuk mengelola data mahasiswa berupa penambahan data mahasiswa baru atau mengubah data yang telah ada. Terdapat data yang harus diisi yaitu NPM, nama, fakultas, program studi, jenis kelamin, dan tahun pemilihan. Untuk tahun pemilihan akan terisi secara otomatis sesuai dengan tahun digunakannya sistem ini. Terdapat tabel untuk menampilkan data mahasiswa yang telah mendaftar dalam pemilihan mahasiswa berprestasi.

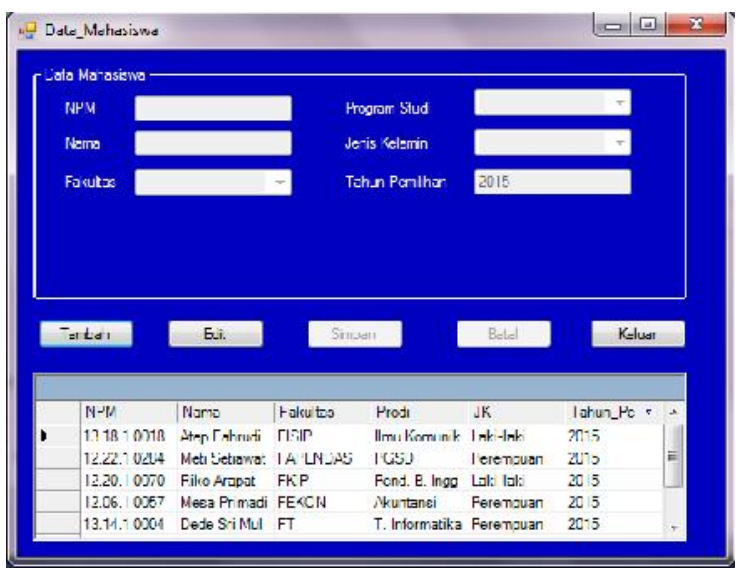

Gambar 5 Tampilan Data Mahasiswa

\section{Form Data Bahan}

Form ini digunakan untuk menentukan bobot dari setiap kriteria yang ada. Penentuan bobot ini dilakukan dengan cara perhitungan menggunakan metode AHP, yaitu dengan melakukan perbandingan berpasangan antar kriteria. Pada form ini juga dilakukan perhitungan IR untuk menentukan data yang telah dimasukkan dapat digunakan atau tidak.

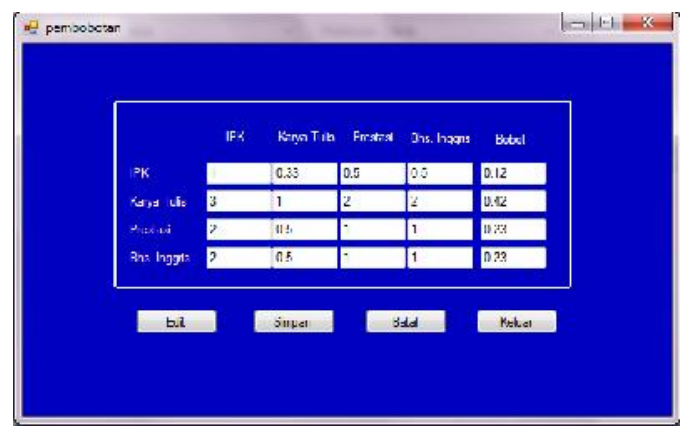

Gambar 6 Tampilan Pembobotan

\section{Form Penilaian}

Form ini digunakan untuk memasukan nilai yang didapat mahasiswa. Terdapat data mahasiswa yang harus diisi untuk menentukan mahasiswa yang akan dinilai. Untuk memasukan atau merubah nilai mahasiswa yaitu dengan cara menekan tombol edit. Data yang harus dimasukkan yaitu IPK, nilai tulisan dan presentasi KTI, prestasi, dan bahasa inggris. Untuk melakukan penilaian terhadap prestasi/kemampuan yang diunggulkan dilakukan pada form prestasi, kemudian hasil nilaianya secara otomatis akan tampil pada form ini. Terdapat tabel yang akan menampilkan data nilai mahasiswa yang diperoleh.

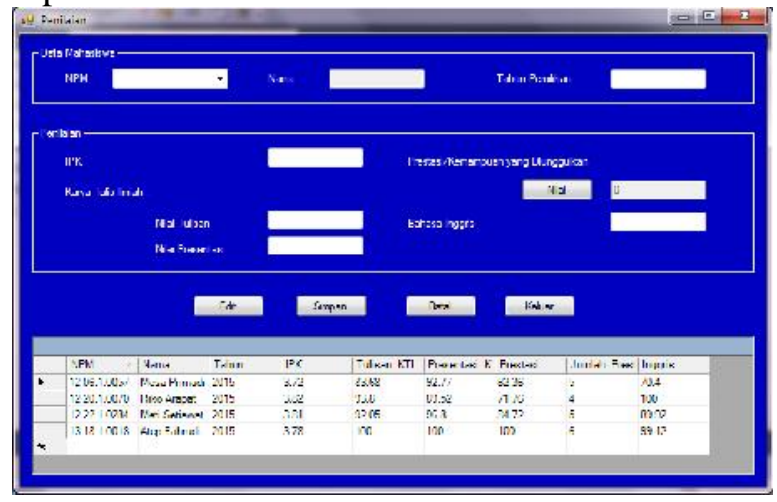

Gambar 7 Tampilan Penilaian

\section{Form Prestasi}

Form ini digunakan untuk mengelola data prestasi/kemampuan yang diunggulkan berupa penambahan data prestasi baru atau mengubah data yang telah ada. Terdapat data NPM, nama dan tahun pemilihan yang akan terisi secara otomatis sesuai dengan data mahasiswa yang sedang di nilai pada form penilaian. Ketika menambah data baru akan dilakukan pengecekan jumlah prestasi yang telah didaftarkan mahasiswa tersebut, jika sudah terdapat 10 prestasi maka tidak akan dapat dilakukan penambahan data. Untuk mendaftarkan prestasi yang diunggulkan yaitu dengan mengisi nama prestasi, pencapaian yang diraih, sesuai bidang, tahun peroleh, lembaga pemberi, individu/kelompok, dan tingkat. ID prestasi akan terisi secara otomatis, dan ketika telah selesai memasukkan semua data maka akan tampil nilai yang diperolehnya. Kemudian akan dilakukan perhitungan jumlah nilai yang didapat untuk ditampilkan pada form penilaian sebagai nilai prestasi yang didapat mahasiswa tersebut. 


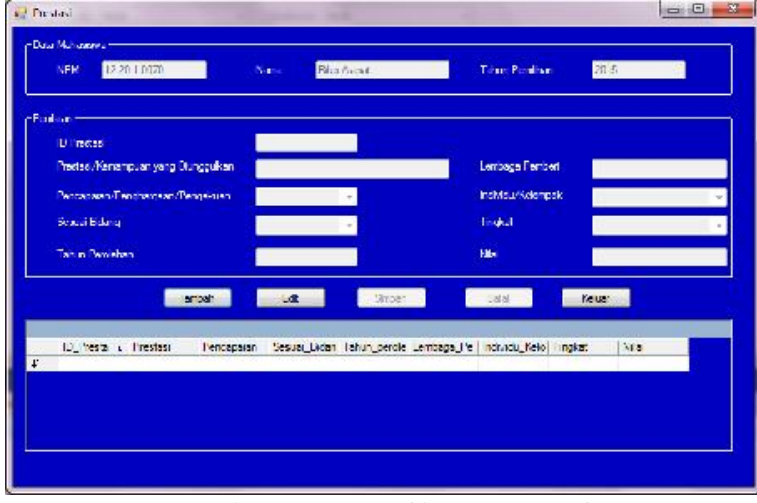

Gambar 8 Tampilan Prestasi

\section{Form Perangkingan}

Form ini digunakan untuk menampilkan hasil perhitungan nilai seluruh kriteria yang didapat mahasiswa beserta totalnya. Data yang ditampilkan yaitu data nilai mahasiswa yang mengikuti pemilihan mahasiswa berprestasi sesuai dengan tahun yang dimasukkan. Mahasiswa akan diurutkan berdasarkan nilai total terbesar dan diberikan peringkat. Data tersebut dapat dicetak untuk mengetahui peringkat tiap mahasiswa dan menentukan mahasiswa yang menjadi pemenang mahasiswa berprestasi di Universitas Majalengka.

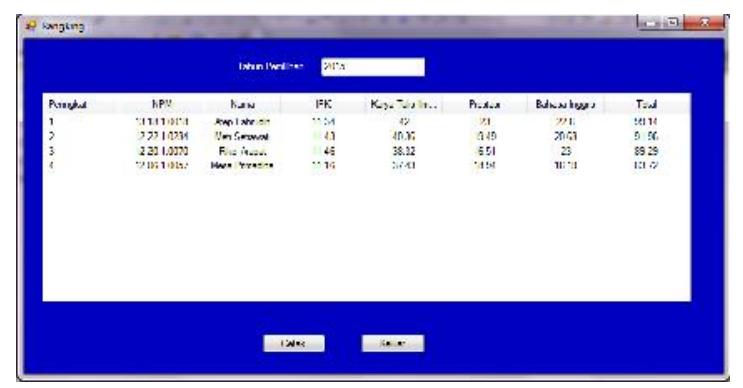

Gambar 9 Tampilan Perangkingan

\section{Form Laporan}

Form ini berisi tampilan laporan sesuai dengan data yang diinginkan, kemudian laporan tersebut dapat dicetak. Terdapat beberapa data yang dapat dipilih dan dijadikan laporan, yaitu laporan data admin, laporan data mahasiswa, laporan data penilaian yang didapatkan mahasiswa, dan laporan daftar prestasi mahasiswa. Data tersebut dapat disaring berdasarkan NPM, dan tahun pemilihan. Laporan yang dipilih akan ditampilkan terlebih dahulu formatnya, sehingga dapat diketahui sudah sesuai yang diinginkan atau tidak. Tekan tombol cetak untuk mecetak laporan yang telah dipilih.

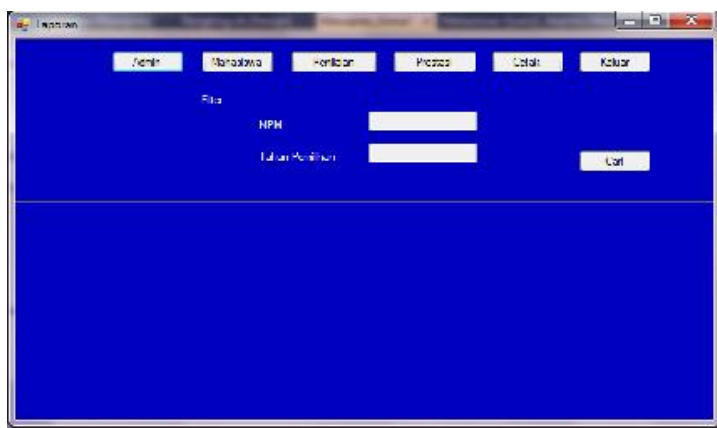

Gambar 10 Tampilan Laporan

\section{KESIMPULAN}

Dari hasil uraian yang telah dijelaskan pada bab-bab sebelumnya, maka penulis dapat menarik kesimpulan sebagai berikut :

1. Dalam proses pengambilan keputusan untuk pemilihan mahasiswa berprestasi melalui empat tahap yaitu membuat hierarki, penilaian kriteria, menentukan prioritas, dan mengukur konsistensi.

2. Kriteria yang digunakan pada sistem ini mengacu pada pedoman pemilihan mahasiswa berprestasi yang diterbitkan oleh DIKTI tahun 2015, yaitu IPK, karya tulis ilmiah, prestasi/kemampuan yang diunggulkan, dan bahasa Inggris.

Sistem Pendukung Keputusan yang dibuat dengan menggunakan metode AHP melakukan perhitungan secara otomatis ketika user menginputkan nilai, sehingga dapat mengurangi masalah dalam pengambilan keputusan penentuan mahasiswa berprestasi.

\section{PUSTAKA}

Asfi, M. dan R.P. Sari. 2010. Sistem Penunjang Keputusan Seleksi Mahasiswa Berprestasi Menggunakan Metode AHP (Studi Kasus: STMIK CIC Cirebon). Jurnal Informatika. 6 (2). 131-144.

DIKTI. 2015. Pedoman Pemilihan Mahasiswa Berprestasi Program Sarjana. Jakarta: Direktorat Jendral Pembelajaran dan Kemahasiswaan Kementrian Riset, Teknologi dan Pendidikan Tinggi.

Hartati, S., S. Kusumadewi, A. Harjoko, dan R. Wardoyo. 2006. Fuzzy Multi-Attribute Decision Making (FUZZY $M A D M)$.Edisi 1. Graha Ilmu. Yogyakarta. 
Hidayatullah, P. 2014. Visual Basic.net membuat aplikasi database dan program kreatif. Edisi 1. INFORMATIKA. Bandung.

Kroenke, D.M. 2005. Database Processing Dasar-dasar, desain \& implementasi. Edisi 9. Erlangga.

Kusrini. 2007. Konsep dan Aplikasi Sistem Pendukung Keputusan. Edisi 1. ANDI. Yogyakarta.

Magdalena, H. 2012. Sistem Pendukung Keputusan untuk Menentukan Mahasiswa Lulusan Terbaik di Perguruan Tinggi (Studi Kasus STMIK Atma Luhur Pangkalpinang). Seminar Nasional Teknologi Informasi dan Komunikasi.10 Maret 2012, Yogyakarta, Indonesia. Hal. 4956

Nurhayati, S. Dan S. Supatmi. 2014. Penerapan AHP untuk Seleksi Mahasiswa Berprestasi. Majalah Ilmiah Unikom. 12 (2). 251-258.

Pressman, R.S. 2012. REKAYASA PERANGKAT LUNAK - BUKU SATU, Pendekatan Praktisi. Edisi 7. ANDI. Yogyakarta.

Shalahuddin, M. Dan Rosa A.S. 2013. Rekayasa Perangkat Lunak Terstruktur dan Berorientasi Objek. Edisi 1. INFORMATIKA. Bandung.

Sari, N.M., B. Widada dan T. Susyanto. 2014. Sistem Pendukung Keputusan Pemilihan Mahasiswa Berprestasi Menggunakan Metode Analytical Hierarchy Process (AHP). Jurnal TIKomSiN. 2 (1). 48-55.

Sianipar, R.H. 2014. Pemrograman Visual Basic.net. Edisi 1. INFORMATIKA. Bandung.

Simarmata, J. 2010. Rekayasa Perangkat Lunak. Edisi 1. ANDI. Yogyakarta.

Sonatha, Y. dan M. Azmi. 2010. Penerapan Metode AHP dalam Menentukan Mahasiswa Berprestasi. Poli Rekayasa. 5 (2). 128-136

Triseptian, A. 2009. Pengembangan Sistem Informasi Berbasis Web Untuk Sistem Informasi Akademik Univeritas Atma Jaya Yogyakarta (studi kasus : Univeritas Atma Jaya Yogyakarta). Tugas Akhir. Fakultas Teknologi Industri Universitas Atma Jaya, Yogyakarta.

Tim Penerbit ANDI. 2009. Pengembangan Sistem Pakar Menggunakan Visual Basic. Edisi 2. ANDI. Yogyakarta.

Utami, E. dan A.D. Hartanto. 2012. Sistem Basis Data menggunakan Microsoft SQL Server 2005. Edisi 1. ANDI. Yogyakarta.

WAHANA KOMPUTER. 2012. Aplikasi Database untuk Tugas Akhir Menggunakan Visual Basic 2010. Edisi 1. ANDI. Yogyakarta.

Yulianto, A. 2014. Sistem Pendukung Keputusan Pemilihan Mahasiswa Berprestasi di Fakultas Matematika dan Ilmu Pengetahuan Alam Universitas Negeri Yogyakarta dengan Metode Ahp dan Topsis. Skripsi. Fakultas Matematika dan Ilmu Pengetahuan Alam Universitas Negeri Yogyakarta. 